\title{
Blended Learning on Vocational High School in Adaptation of New Habit Era with Whole of Government Approach
}

\author{
Wydha Mustika Maharani* \\ Doctoral Program of Administrative Science \\ Brawijaya University \\ Malang, Indonesia \\ *Wydhamustika7@gmail.com
}

\author{
Soesilo Zauhar, Mochamad Makmur, \\ Bambang Santoso Haryono \\ Faculty of Administrative Science \\ Brawijaya University \\ Malang, East Java
}

\begin{abstract}
The worldwide students can feel the COVID-19 pandemic impact, such as closing schools and learning online. However, it is feared that it could increase the drop-out rate and year repetition, especially at vocational schools. Even during this pandemic, teaching and learning activities must continue. So, the right strategy is needed to collaborate effective learning methods like blended learning with existing government policies through the whole of government (WoG). The objective of this research is to explore strategies used in blended learning in vocational high school education in the adaptation of a new habit era through the WoG approach. This research used a descriptive qualitative approach. The data was collected from a literature study or secondary data research. Data collection was carried out through a theoretical review through a literature review by exploring empirical facts to obtain comprehensive data. Blended learning as an effective learning method needs a WoG concept to implementing it in a vocational high school, it because that WoG can integrate various sector including regional elements, Public Health Office, COVID-19 Task Force, Business and Industry, University, SEAMOLEC (Southeast Asian Ministers of Education Organization), and related agencies to achieve the goal of implementing blended learning in vocational high schools, familiarizing students with the COVID-19 protocol, forming new habit adaptation characters (AKB), and evaluating school readiness in implementing internship from home.
\end{abstract}

Keywords-new habit adaptation, vocational high school, whole of government

\section{INTRODUCTION}

The Indonesian economy continues to increase from year to year and ranks 10th in the world economy in purchase power balance [1]. Indonesia is also ranked 4th in Southeast Asia after China, Japan, and South Korea [2]. In 2030, Indonesia can be ranked 7 th in the world economy if the productivity of human resources is continuously improved. Currently, Indonesia only has around 55 million skilled workers, 58 million more skilled workers are still needed to reach the 2030 target. That means it needs 3.8 million skilled workers per year. The steps to creating skilled human resources are through vocational education [3]. Vocational education is an integral part of the education sector globally and can increase community capacity, contribute to individual development, and several other goals that are not implemented in other education sectors. According to Billet [4], vocational education has great potential to involve students in programs and institutions to increase their experience. The learning process in vocational education can be related to specific jobs, related to broad jobs, or a combination of the two, including formal education [5].

Vocational education has a close relationship with the economy and professional development [6]. Through, the vocational high school graduates are expected to contribute the nation's competitiveness, both in products, services, and preparation of human resources, because the better the implementation of vocational education, the higher the level of industrial development at the national level and able to improve people's welfare. However, the problem in vocational education in Indonesia is the number of students who repeat and drop out of school is still high (Figure 1), causing an increase in unemployment in Indonesia. It can also reduce people's interest in attending vocational schools because, in Indonesia, the passing rate (accreditation status) is a consideration for parents in choosing a school for their children [7].

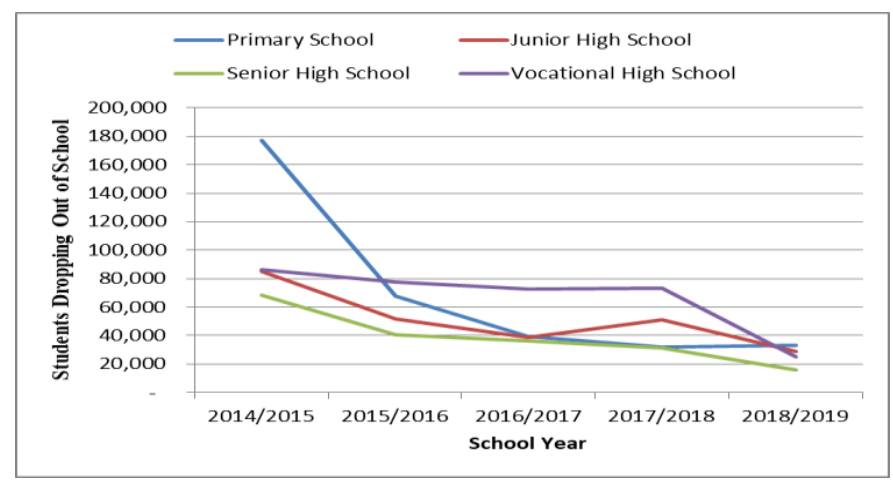

Fig. 1. Total of drop out students based on each education level in Indonesia. 
Although the high dropout rate from vocational education, the industrial sector usually requires graduates who have skills at work [8], which makes vocational education very important. However, the challenges of vocational education are currently increasing because of the COVID-19 pandemic. This pandemic requires every country to strive to adapt and live alongside with COVID-19 through the idea of "New Normal". This idea will play a significant role in various sectors because the pandemic has almost totally stopped economic activities and changed the community's social behavior [9]. The Education Sector is also inseparable from the impact of COVID-19, which requires the education sector to adopt digital technology in the context of New Habit Adaptation (IMR).

Learning methods that can be applied today are distance learning methods that take advantage of technological developments to catch up. Distance education has been implemented by many countries for approximately 150 years for various vocational, professional, and training courses, even before the COVID-19 pandemic broke out. Initially, distance education was used by universities and focused on learning certain materials, but later began to be applied to students who could not attend school regularly [10]. The full application of distance learning considers less effective for vocational secondary education because many schools have limited resources. UNDP [11] states that this pandemic has shown the vocational education and training system's vulnerability, like weak digitization and structural weakness. So, it takes a learning pattern that can combine distance learning and face-toface, which is called Blended Learning. It can be done considering that the Directorate General of Vocational Education issued a Circular Letter No. 2 of 2020 concerning the Implementation of Vocational Education Learning in the Corona Virus Disease (COVID-19) Pandemic where the regulation contains about schools in the green zone being able to carry out face-to-face learning while still implementing the provisions according to health protocols. So, the learning method that can be used to optimize and efficiently carried out the study is blended learning.

Indonesia's current conditions and the number of learning methods that want to be applied raise questions about how blended learning can be applied to vocational high schools to adapt to new habits when the COVID-19 pandemic is still endemic in Indonesia. Besides, what is the role of stakeholders in accommodating new habits in vocational high schools in Indonesia?

\section{LITERATURE REVIEW}

\section{A. Blended Learning}

Blended learning is a learning method that is created in response to technological developments. Blended learning integrates distance learning and traditional learning (face to face). Blended learning can also be used to solve challenges in learning and individual student development. Blended learning configures itself in a new normal and can improve the teaching and learning process in an educational environment that is more responsive to the lifestyle of contemporary students because blended learning supports reduced costs, time efficiency, and location limitations [12,13].

The conceptual model of blended learning consists of 4 quadrants (Figure 2), namely 1) quadrant 1: live synchronous learning, learning in class that is usually done in schools with face-to-face interactions between teachers and students; 2) quadrant 2: virtual synchronous learning, learning that is carried out in cyberspace using various video conferencing technologies; 3) quadrant 3: collaborative asynchronous learning, learning that is carried out together with other people anytime and anywhere, for example by discussing, or working together in online discussion forums; and 4) quadrant 4: selfdirected asynchronous learning, learning which is done independently by reading, seeing, listening through radio, television, or podcasts [14].

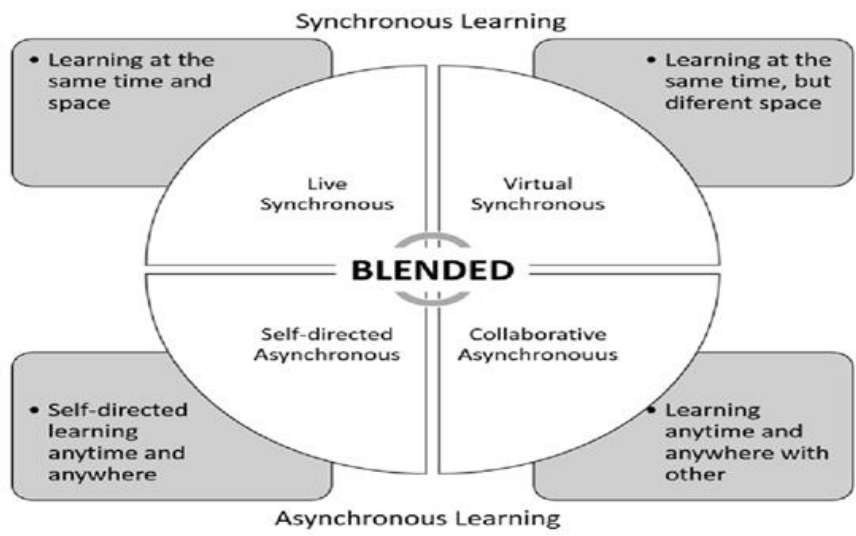

Fig. 2. Blended learning quadrant [14]

\section{B. Whole Government}

The whole of Government (WoG) is an approach to governance that brings together the government's collaborative efforts from across sectors within a broader scope of coordination to achieve development, policy, program management, and public service goals. WoG has been implemented in various countries in serving the community. It is very appropriate to apply in Indonesia, with the principle of collaboration and the principle of one goal so that the background in service can refer to the principles of effectiveness and efficiency. WoG emphasizes integrated services so that the principles of collaboration, togetherness, unity in serving community requests can be completed in a short time. WoG is the interagency approach, which is an approach that involves several agencies related to relevant affairs.

WoG approach is an evolution of the New Public Management (NPM) approach, emphasizing efficiency aspects, and encouraging sectoral egos compared to the sector integration perspective. WoG emphasizes the togetherness aspect and removes sectoral barriers that have been built up in the New Public Management model. WoG is not a new 
concept, because previously there was a Join Up Government (JUG) introduced by Tony Blair. These concepts emphasize a more holistic strategy and using social sciences rather than economics in government policies. The function of both concepts is to create horizontal and vertical government coordination. It is crucial because in terms of coordination, the integration problem was the primary concern behind these reform initiatives $[10,15]$. So, WoG emphasizes the unification of government elements as a whole and this concept can replace the old doctrine of coordination in public administration studies [16].

WoG is essential to be implemented, and this is based on several reasons, namely: First, there are external factors such as public encouragement in realizing policy integration, development programs, and services to create better governance, besides the development of information technology. Second, the phenomenon of sectoral capacity imbalance from the nuances of competition between sectors in development. Differences in sector orientation in development can lead to the growth of sectoral egos, which encourage the behavior and values of individuals and groups that narrow to the sector's interests. Third, the diversity of background values, culture, customs, and other forms of background encourages the nation's disintegration. As a formal institution, the government is obliged to encourage the growth of national adhesive values that will ensure the unity of these national elements in one frame of the Republic of Indonesia [17].

\section{METHODOLOGY}

This study uses qualitative methods through library research techniques. The findings from literature study research also have the advantage of being more conclusive than the findings of just one preliminary study [18]. Data were collected from policies, books, article, and relevant research results related to the application of blended learning. Descriptive analysis was used to answer the research problems, which is then discussed based on existing theories to reach conclusions.

\section{RESULTS AND DISCUSSION}

\section{A. Blended Learning in Vocational High Schools in the New Normal Era}

Following the joint decision from the Ministry of Education and Culture, Ministry of Religion, Ministry of Health, and Ministry of Home Affairs regarding the implementation of learning in the academic year 2020/2021 during the COVID-19 pandemic resulted in a decision that schools in the green zone may carry out face-to-face learning as which is stated in the Circular Letter of the General Directorate of Vocational Education No. 2 of 2020. Meanwhile, vocational high schools in the orange, yellow and red zones may not hold face-to-face learning and continue teaching and learning activities from home because the spread of COVID-19 is swift and difficult to control, especially in the school environment. It is because COVID-19 can stick to students' equipment, such as door handles, shaking hands with friends, school benches, practical tools, and others.

The high-speed transmission of COVID-19 has an impact on the efficiency of learning activities in schools. Schools can slow the spread of this virus to instill insights into personal hygiene, use of masks, and maintain distance. Also, the application of blended learning is something that must be done during this pandemic. SMKN 9 Bandung has successfully implemented blended learning; this is because blended learning can improve student learning outcomes and can form a social environment between students [19] and this makes SMKN 9 Bandung currently used as a pilot project in the preparation of the COVID-19 emergency curriculum module. The best way to slow down the transmission of COVID-19 is to have good insight into how to prevent the spread of COVID-19 in schools. SMKN 9 Bandung, West Java in implementing blended learning by carrying out eight stages, including:

- Put through decision letter to form a COVID-19 task force in schools

- COVID-19 standard operating procedure (SOP) in schools

- Preparing facilities and infrastructure, such as providing Mobile Sterilization Chamber, thermometer gun, increasing handwashing areas

- Socialization of the implementation of the Covid-19 protocol and standard operating procedure

- Learning and teaching activity management system (KBM)

- Data collection on students based on domicile and the means of transportation used

- Funding and partnerships

- Increasing teacher competence

Based on this, in the implementation of Blended Learning, the schools must make firm policies regarding attendance and cleanliness of the school environment. Schools in the green zone can carry out face-to-face activities while still paying attention to health protocols and limiting the number of students attending school. Restrictions on student attendance can be done by making face-to-face schedules only for vocational practice activities and discussions. When face-toface takes place, school time must also be reduced, adjusting to the optimal time for learning. Teaching and learning activities using online media can be carried out outside to provide materials and assignments. Schools must be able to prepare integrated online learning media such as LMS (Learning Management System). This LMS will make it easier for teachers to evaluate students because assessment activities are the key to success in blended learning [3]. Teachers must also be able to communicate actively to be able to evaluate material and provide motivation to students so that students do not experience difficulties in the future. 


\section{B. Whole of Government Adoption to Accommodate the New Normal}

The implementation of blended learning in vocational schools during the adaptation of new habits requires collaboration between stakeholders. Stakeholders involved in the application of this blended learning include (1) territorial elements (RT, RW, Lurah, Camat); (2) Public Health Center; (3) Health Office; (4) COVID-19 task force; (5) partner institutions (State Universities, Private Universities and Industry); SEAMOLEC; and (7) related agencies. Accommodating the adaptation of new habits in the vocational high school environment needed strong coordination. This collaboration will create environmental conditions suitable for traditional and distance student learning. To carry out face-toface learning activities, schools must establish communication with the regional elements of the school to not cause problems later. The Public Health center, the Health Office, and the COVID-19 Task Force must work together to monitor and evaluate face-to-face student learning in schools. Related agencies must also provide internet access for students so that distance learning can take place optimally and efficiently. Public sector institutions, which are also associated with internships, must also adapt to new habit patterns that require students to do an online internship and reduce face-to-face contact. It is because student internships are needed in the industrial sector and can be an opportunity to get better human resources. Internship impacts student skills and helps students understand the performance of industrial sectors through hands-on work experience [20,21]. Ko and Sidhu [22] explained that an internship program could increase students' choice to work in the public sector.

However, the number of students who can do internships from vocational education has decreased due to the COVID-19 pandemic because of limited space and interaction. One of the schools affected by this is SMKN 9 Bandung, which has seen a decline in the number of industries accepting street vendors (Figure 3).

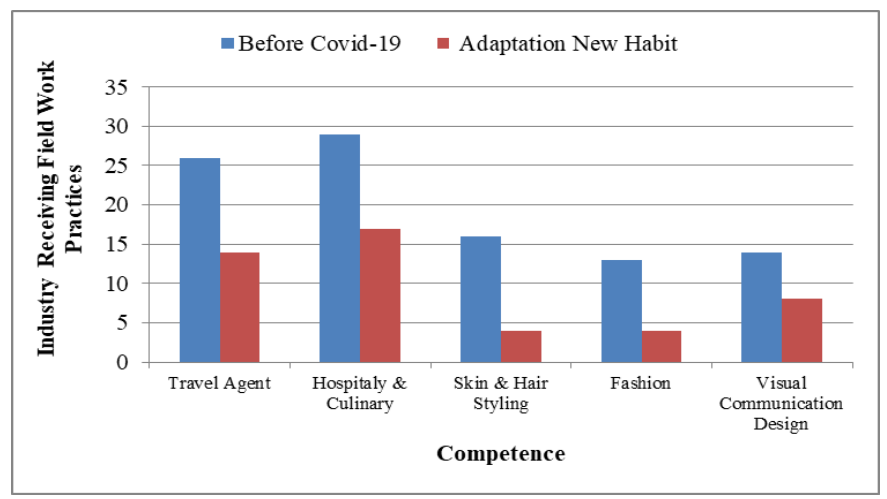

Fig. 3. Data of readiness industries to receive internship in adaptation to new habits.
The industrial revolution 4.0 requires every sector in a country to adapt, synergize, and apply increasingly advanced technology. Internship activities are vital activities that cannot be replaced in vocational education because doing PKL can increase students' experience and ability to deal with problems and apply the knowledge gained during the education period. It encourages SMKN 9 Kota Bandung to be able to innovate and develop strategies so that students can do street vendors with industry; these strategies include:

- Internship from Home, which can be done remotely with assessments and attendance based on results of the finished work sent via email

- Collaborating, an internship in industrial places, cooperation with industry (TEFA) through practice in schools, bringing in guest teachers or vocational instructors

- Utilizing distance learning media through video conferencing, live streaming, Instagram, and Youtube

According to the Directorate of Vocational Schools, internship activities can be carried out with the duration agreed by the institution with an agreement before. If it cannot be implemented because of places' unavailability, students can carry out project-based learning tasks and problems guided by the teacher and industry and the world of work (IDUKA). Also, students can carry out entrepreneurial activities with the guidance of teachers [23].

\section{CONCLUSION}

A significant step to optimize vocational education's learning process is to combine distance learning and face-toface learning, called blended learning. This combination learning method can improve learning outcomes because the material obtained from online learning can be re-learned through face-to-face learning also as a step to decrease the transmission of a virus. One of the significant steps that can be taken by the government in a country to accelerate the opening of schools and other educational institutions is to reduce the transmission of the COVID-19 [11]. To support the learning activities in the green zone areas, the school must pay attention to the procedures for managing facilities and infrastructure with the rules of adapting to new habits (new normal) and suitable for teaching and learning activities. In adapting this combined learning, the government's role through the whole of government concept is significant because, in the application of New Habit Adaptation (AKB), it is necessary to involve various sectors of government and education to implementing blended learning in vocational high schools, familiarizing students with the COVID-19 protocol, forming new habit adaptation characters (AKB), and evaluating school readiness in implementing internship from home. 


\section{REFERENCES}

[1] World Bank, "The World Bank in Indonesia," 2020. [Online]. Retrieved from: https://www.worldbank.org/en/country/indonesia/overview [Accsessed on: 02/10/2020].

[2] S. Elias and N. Clare, The Growth and Development of the Indonesian Economy. Australia: RBA Bulletin, Reversed Bank Australia, 2011.

[3] A. Rizkiyah, "Penerapan Blended Learning Untuk Meningkatkan Hasil Belajar Siswa Pada Mata Pelajaran Ilmu Bangunan di Kelas X TGB SMK Negeri 7 Surabaya," Jurnal Kajian Pendidikan, vol. 1, no. (2015), pp. 40-49, 2015.

[4] S. Billet, Vocational Education Purposes, Traditions and Prospects. Queensland: Springer Science Business Media B.V, 2011.

[5] P. Descy and M. Tessaring, Training and Learning for Competence: Second Report on Vocational Training Research in Europe. Italy: European Centre for the Development of Vocational Training, 2001.

[6] G. Mouzakitis, "The role of vocational education and training curricula in economic development," Procedia Social and Behavioral Sciences, vol. 2, no. (2), pp. 3914-3920, 2010.

[7] N. Kristiani, "Faktor-Faktor yang Mempengaruhi Keputusan Orang Tua Siswa Memilih SD Kasattriyan Surakarta," Jurnal Manajemen Maranatha, vol. 16, no. (1), pp. 91-118, 2016.

[8] E. Russel, "Making a Maths Degree Work for the Workplace," Higher Pedagogies, vol. 3, no. (1), pp. 403-416, 2018.

[9] P.S. Winanti and W. Mas'udi, New Normal: Perubahan Sosial Ekonomi dan Politik Akibat COVID-19. Yogyakarta: Gajah Mada University Press, 2020.

[10] L. Moran and G. Rumble, Vocational education and training through open and distance learning. New York: RoutledgeFalmer, 2004.

[11] UNDP, Policy Brief: Education during COVID-19 and Beyond. United Nations, 2020.

[12] R. Brown, "Blending Learning: Rich Experience form Rich Picture," Training, and Development in Australia, vol. 30, no. (3), pp. 14-17, 2003.
[13] C. Dziuban, C.R. Graham, P.D. Moskal, A. Norberg, and N. Sicilia, "Blended learning: the new normal and emerging technologies," International Journal of Educational Technology in Higher Education, vol. 15, no. (3), pp. 1-16, 2018.

[14] U.A. Chaeruman and M. Santi, "Quadrant of Blenden Learning: a Proposed Conceptual Model for Designing Effective Blended Learning," Jurnal Pembelajaran Inovatif, vol. 1, no. (1), pp. 1-5, 2018.

[15] T. Christensen and P. Lægreid, "The whole-of-government approach to public sector reform," Public Administration Review, vol. 67, no. (6), pp. 1059-1066, 2007.

[16] C. Hood, "The Idea of Joined-Up Government: A Historical Perspective," in V. Bogdanor, Joined-Up Government. Oxford: British Academy Scholarship Online, 2005.

[17] F.A. Gafar, "Analisis Implementasi Whole of Government (WoG) Pelatihan Dasar Calon Pegawai Negeri di Badan Pendidikan dan Pelatihan Jawa Timur," Jurnal Manajemen Bisnis dan Inovasi, vol. 5, no. (3), pp. 151-158, 2018.

[18] J.D. Baker, "The Purpose, Process, and Methods of Writing a Literature Review," AORN Journal, vol. 103, no. (3), pp. 265-9, 2016.

[19] T.M. Indriani, F. Toto, and R. Cepi, "Implementasi Blended Learning dalam Program Pendidikan Jawak Jauh Pada Jenjang Pendidikan Menengah Kejuruan,” EDUTCEHNOLOGIA, vol. 2, no. (2), pp. 129139, 2018.

[20] R.B. Denhardt, "The big questions of public administration education," Public Administration Review, vol. 61, no. (5), pp. 526-534, 2001.

[21] M. Holzer and W. Lin, "A longitudinal perspective on MPA education in the United States," Journal of Public Affairs Education, vol. 13, no. (2), pp. 345-364, 2007.

[22] K. Ko and D.J.K. Sidhu, "The Impact of Internship in Public Organizations on University Students' Perceptions and Career Choice," International Review of Administrative Sciences, vol. 78, no. (4), pp. 710-732, 2012.

[23] Direktorat Sekolah Menengah Kejuruan, Panduan Praktis Pembelajaran SMK pada Masa Kebiasaan Baru (New Normal). Jakarta: Direktorat SMK, 2020. 